\title{
A Retrospective Study of Clinical and Laboratory Profile of Dengue Fever in Tertiary Care Hospital, Wardha, Maharashtra, India
}

\author{
Praful S. Patil ${ }^{1}$ D, Dhruba Hari Chandi ${ }^{1}$, Smita Damke $^{1}$, Shital Mahajan $^{1}$, \\ R. Ashok ${ }^{2 *}$ and Silpi Basak ${ }^{1}$ \\ ${ }^{1}$ Department of Microbiolgy, JNMC, Sawangi( Meghe) Wardha - 442 004, Maharashtra, India. \\ ${ }^{2}$ Govt. Medical College, Dungarpur - 314 001, Rajasthan, India.
}

\begin{abstract}
Dengue disease is caused by dengue virus which is a vector born viral infection. The prevalence of dengue has increased dramatically from past few decades. The clinical symptoms vary from asymptomatic to severe hemorrhagic fever leads to high morbidity and mortality. Method-This retrospective study was carried out during January 2019 to December 2019. The laboratory test was done by using J Mitra \& Co on Day 1 of their visit to the hospital which shows NS1, IgM and IgG reactivity towards dengue fever. The clinical profile information data was collected from patient records. Out of 640 samples $62.18 \%$ (398) was positive. The percentage of positive males and females were $60.78 \%, 64.23 \%$ respectively. The highest prevalence of dengue infection was observed more in age group between 31-40 years (81.69\%) and least prevalence in age group $71-80$ years $(36.36 \%)$. Most of the patients were positive for NS1Ag121 (30.4\%) followed by IgM positive 87 (21.9\%) \& 59 (14.8\%) positive for both IgM and NS1 Ag The highest number of infections was seen during October (75.8\%) post monsoon season. All patients had a fever, followed by head ache $(82 \%)$ and body pains $(66.4 \%), 64.84 \%$ stayed in the hospital less than $\mathbf{5}$ days. In tropical and sub-tropical regions dengue is still a leading public health problem especially during rainy and post monsoon seasons. Both NS1 Ag and IgM detection in early acute phase has potential diagnostic value. So, to reduce mortality there need to initiate community-based cohort studies to predict the pace of dengue spread based on clinical presentation and laboratory findings during epidemics in India. Aedesaegypti is a common vector for transmission of DENV, CHIKV and ZIKV, so there is a need to screen for these infections in endemic areas.
\end{abstract}

Keyword: Dengue, (NS1)Nonstructural Protein I, Immunoglobulin G( IgG), Immunoglobulin M (IgM)

\begin{abstract}
*Correspondence: ashokrnims@yahoo.co.in
(Received: May 02, 2020; accepted: July 24, 2020)

Citation: Patil PS, Chandi DH, Damke S, Mahajan S, Ashok R., Basak S. A Retrospective Study of Clinical and Laboratory Profile of Dengue Fever in Tertiary Care Hospital, Wardha, Maharashtra, India. J Pure Appl Microbiol. 2020;14(3):1935-1939. doi: 10.22207/JPAM.14.3.32

(C) The Author(s) 2020. Open Access. This article is distributed under the terms of the Creative Commons Attribution 4.0 International License which permits unrestricted use, sharing, distribution, and reproduction in any medium, provided you give appropriate credit to the original author(s) and the source, provide a link to the Creative Commons license, and indicate if changes were made.
\end{abstract}




\section{INTRODUCTION}

Dengue feveris an acute arboviral infection cause by a dengue virus, there are four distinct serotypes (DENV1, DENV2, DENV3, and DENV4) of this virus transmitted by Aedesaegypti ${ }^{1}$. The clinical symptoms vary from asymptomatic to severe hemorrhagic fever leads to high morbidity and mortality(20\%) if left untreated. The prevalence of dengue has increased dramatically from past few decades and now about half of the population of world areis at risk ${ }^{2,3,4}$. Dengue transmission occurs throughout the year in endemic tropical areas; however, in most countries there is a distinct seasonal pattern, with increased transmission usually associated with the monsoon and post monsoon season ${ }^{5,6}$. Lack of specific anti viral drug for the treatment of dengue and had variable clinical presentation which is a very big challenge to the clinicians to prevent the complications and death ${ }^{7}$. So to reduce morbidity out during January 2019 to December 2019, in the department of microbiology, at Jawaharlal Nehru Medical College, Wardha, Maharashtra, India. A total of 640 patients with the clinically suspected cases were included in the study. The laboratory test was done by using a rapid solid phase immuno- chromatographic test(J Mitra \& Co. Pvt. Ltd.) on Day 1of their visit to the hospital which shows NS1, IgM and IgG reactivity towards dengue fever. The patient clinical profile such as fever, head ache and length of hospital stay were collected from patient records at MRD (Medical Record Department).

\section{RESULT}

A total of 640 patient's were included in the study. ,The distributions of patient demographic results were shown in the table: 1 , Seropositivity Pattern in dengue fever was shown in the table: 2. Length of hospital stay, Seasonal Variation and

Table 1. Demographic characteristic of Patient $(n=640)$

\begin{tabular}{lccc}
\hline Characteristics & Total no of patients & Positive & Percentage \\
\hline & & Gender & \\
Male & 380 & 231 & 60.78 \\
Female & 260 & 167 & 64.23 \\
& & Age group in years & \\
$01-10$ & 35 & 15 & 42.85 \\
$11-20$ & 92 & 42 & 45.65 \\
$21-30$ & 132 & 98 & 74.24 \\
$31-40$ & 142 & 116 & 81.69 \\
$41-50$ & 124 & 70 & 56.45 \\
$51-60$ & 70 & 39 & 55.71 \\
$61-70$ & 23 & 10 & 43.47 \\
$71-80$ & 22 & 08 & 36.36 \\
& & Geographical distribution & \\
Urban & 274 & 66 \\
Rural & 415 & 124 & 55.1 \\
Total & 225 & 398 & 62.2 \\
& 640 & & \\
\hline
\end{tabular}

and mortality of dengue infection, it is better to understand the clinical profile of disease along with the laboratory parameters of dengue fever. This current retrospective study was carried out to determine, the seasonal distribution, demographic variation with clinical manifestations of all laboratory tested dengue cases.

\section{METHODOLOGY}

This retrospective study was carried
Table 2. Seropositivity Pattern in dengue fever

\begin{tabular}{lcc}
\hline Parameters & Number & Percentage \\
\hline NS1 Ag & 59 & 14.82 \\
IgMAbs & 87 & 21.86 \\
IgGAb & 44 & 11.06 \\
NS1 Ag and IgMAb & 121 & 30.40 \\
NS1 Ag and IgGAb & 40 & 10.05 \\
IgM and IgGAbs & 47 & 11.81 \\
Total & 398 & 100 \\
\hline
\end{tabular}


clinical profile of dengue infections were shown in the tables: $3,4, \& 5$ respectively. The mean age was $35.03 \pm 5.07$ years old and Standard deviation $\sigma$ is 16.6188. Mean Length of hospital Stay (Mean \pm SD) $=3.65 \pm 1.39$, Range:2-7 days

Table 3. Length of hospital stay in In-patients

\begin{tabular}{lcc}
\hline $\begin{array}{l}\text { Length of } \\
\text { hospital stay }\end{array}$ & $\begin{array}{c}\text { Study } \\
\text { population }\end{array}$ & $\%$ \\
\hline$\leq 5$ days & 200 & 83.68 \\
$>5$ days & 39 & 16.32 \\
Total & 239 & 100 \\
\hline
\end{tabular}

Table 4. Seasonal Variation of dengue Infections

\begin{tabular}{|c|c|c|c|c|}
\hline \multirow{2}{*}{$\begin{array}{l}\text { Months } \\
\text { Wards }\end{array}$} & \multicolumn{2}{|c|}{$\begin{array}{c}\text { Total number of } \\
\text { patients }\end{array}$} & \multirow[t]{2}{*}{$\begin{array}{c}\text { Number of } \\
\text { positive patients }\end{array}$} & \multirow[t]{2}{*}{ percentage } \\
\hline & $\overline{\mathrm{OPD}}$ & $\overline{I P D}$ & & \\
\hline January & 07 & - & 01 & 14.28 \\
\hline February & 18 & - & - & 0 \\
\hline March & 11 & - & - & 0 \\
\hline April & 08 & - & - & 0 \\
\hline May & 01 & - & - & 0 \\
\hline June & 01 & - & - & 0 \\
\hline July & 05 & - & - & 0 \\
\hline August & 16 & 06 & 03 & 13.63 \\
\hline September & 45 & 36 & 53 & 65.43 \\
\hline October & 95 & 62 & 119 & 75.79 \\
\hline November & 96 & 75 & 121 & 70.76 \\
\hline December & 98 & 60 & 101 & 63.92 \\
\hline \multirow[t]{2}{*}{ Total } & \multirow{2}{*}{\multicolumn{2}{|c|}{$\begin{array}{l}401 \\
\end{array} 640$}} & 398 & 62.18 \\
\hline & & & & \\
\hline
\end{tabular}

\section{DISCUSSION}

According to $\mathrm{WHO}$, in last 5 decades dengue infections has shot up 30 fold, because of its complex patho-physiological, ecological as well as economical problems ${ }^{8}$. In current study majority of patients were males ( 380 males out of 640 patients)than females, this may due to males are more exposed to mosquitoes in outdoor activity similar findings were reported in Gupta et al. and Dar es Salaam 2014 outbreak ${ }^{9,10}$.

In the current study large number i.e. $81.69 \%$ of dengue cases are from age group between 31 to 40 years which is similar to the study MM Kauser et al. ${ }^{11}$. Kaushik M. et al. ${ }^{4}$ Dhruba et al. ${ }^{1}$, Ghouth et al. ${ }^{12}$ and Padhis et al. ${ }^{13}$ reported that most common affected age group was 11-20 years, the difference may be the study population and sample size. In the present study positive rate was high in urban population compared to the rural population. Urbanization tends to increase the number of habitats suitable for Aedesaegypti. The Aedesaegypti mosquito population was highest in slum houses, shop houses and multistoreyed flats. In the current study highest number of dengue cases were reported in the post-monsoon period similar results were found in study done by Lata R. patel et al. ${ }^{14}$ During monsoon period heavy rains leads to stagnation of large amount of water. These are the favourite breeding places for vector
Table 5. Symptoms distribution in dengue patients

\begin{tabular}{lcc}
\hline Symptoms & $\begin{array}{c}\text { No. of cases } \\
\text { ( } \mathrm{n}=640)\end{array}$ & $\%$ \\
\hline Fever & 640 & 100 \\
Headache & 525 & 82 \\
Body ache & 425 & 66.4 \\
Retro orbital pain & 240 & 37.5 \\
Abdominal pain & 180 & 28.1 \\
Nausea/ vomiting & 121 & 18.9 \\
Conjunctival congestion & 100 & 15.6 \\
Generalised weakness & 95 & 14.8 \\
Joint pain & 65 & 10.2 \\
Anorexia & 41 & 6.4 \\
Diarrhea & 41 & 6.4 \\
Dry cough & 32 & 5 \\
Skin Rash & 24 & 3.8 \\
Bleeding & 20 & 3.1 \\
Bradycardia & 16 & 2.5 \\
\hline
\end{tabular}


mosquito. This may be the cause for more number of cases in post-monsoon season.

Single stranded RNA virus belonging to genus flavivirus, is responsible for acute illness in dengue. 4 to 10 days was the incubation period for dengue fever. Febrile phase, critical phase and recovery phase are these conditions seen in dengue infection ${ }^{9} \& 10$. Overall sero-positivity rate was $62.2 \%$ (398/640). In the current study over all NS1 detection was 220 (49.7\%) patients were positive, Results were correlating with other study by Anitha Chakravarti 35(39.7\%). In dengue infection the role of NS1 Ag for early detection is currently being assess by many investigators, without the requirement of paired sera (Two serum samples taken from a patient usually at 1 week apart)and it circulates uniformly in all serotypes of dengue and there is no cross reaction of dengue NS1 antigen with other flaviviruses ${ }^{13-15}$. The NS1 is produced in high concentration in the serum during acute phase (0-6 days) of infection. The sensitivity varies between 85.5 and $95.9 \%$ and specificity between 95.0 and $100 \%$ using the viral isolation as a reference test ${ }^{16,17}$.

Dengue IgM can be detected within 3-5 days in $50 \%$ people after onset of symptoms, and $80 \%$ after day 5 and to $99 \%$ on day 10 they and not detected after 2-3 months. IgM is not specific, they can cross-reaction with other flaviviruses and also with rheumatoid factor ${ }^{17}$. So if the patient sample is reactive for NS1 Ag and IgM antibodies instead of IgM only, that is more specific. At end of the first week of onset symptoms, IgG antibodies will detect and remain life-long in some patients. Detection of NS1 and IgG, IgM and IgG detection indicates the seroconverstion stage of infection. If only IgG Abs detection in serum, it indicates past infection, secondary infection or cross-reaction with other flaviviruses antigen ${ }^{17}$. In the current study fever was present in all the patients $(100 \%)$, followed by headache and body pains which is similar to the other studies ${ }^{18-20}$. Only $16.32 \%$ were stayed in the hospital more than 5 days which is similar to the other study carried out by Solanke SN et al. at Jalna ${ }^{20}$. In the current study no mortality was found.

\section{CONCLUSION}

In tropical and sub-tropical regions, dengue is still a leading public health problem especially during rainy and post monsoon seasons. An increased urbanization and behavior change in vector is also one cause for increase in dengue cases. Males were most commonly affected. BothNS1 Ag and IgM detection in early acute phase has potential diagnostic value. So, to reduce mortality there need to initiate communitybased cohort studies to predict the pace of dengue spread based on clinical presentation and laboratory findings during epidemics in India. Aedesaegyptiis a common vector for transmission of DENV, CHIKV and ZIKV, so there is a need to screen for these infections in endemic areas.

\section{ACKNOWLEDGMENTS}

None.

\section{CONFLICT OF INTEREST}

The authors declare that there is no conflict of interest.

\section{AUTHORS' CONTRIBUTION}

All authors listed have made a substantial, direct and intellectual contribution to the work, and approved it for publication.

\section{FUNDING}

None.

\section{ETHICS STATEMENT}

Not applicable.

\section{DATA AVAILABILITY}

All datasets generated or analyzed during this study are included in the manuscript.

\section{REFERENCES}

1. Chandi DH. Prevalence of dengue virus infection among population of Bhaili visiting tertiary health institution; Chhattisgarh. Asian J Med Sci. 2020;11(2):30-4. https:// doi.org/10.3126/ajms.v11i2.27345

2. World Health Organization, Regional Office for South-East Asia, 2016. Dengue Bulletin. Vol-39. World Health Organization, Regional Office for SouthEast Asia. Available at: http://www.who.int/iris/ handle/10665/255696. Accessed December 2016.

3. Park K. The Dengue Syndrome. Text book of preventive and social medicine $23 \mathrm{rd}$ ed. Jabalpur, India: $\mathrm{M} / \mathrm{s}$ Banarsidas Bhanot. 2015:246-54.

4. Mid Term Plan for prevention and control of Dengue and Chikungunya. Directorate of National Vector Borne Diseases Control Programme, Directorate General of Health Services, Ministry of Health \& 
Family Welfare, Government of India. 2011. Available at: https://mohfw.gov.in/sites/default/files/5201617. pdf Accessed 10 April 2018.

5. Biswas A, Pangtey G, Devgan V, et al. Indian national guidelines for clinical management of dengue fever. Journal of the Indian Medical Association. 2015;113(12).

6. Yacoub S, Ferrar J. Dengue. In: Farrar J, Hotez P, Junghanss T, Kang G, Lallo D, White N, editors. Manson's Tropical Diseases, Elsevier Limited; 2014;23:162-70.

7. World Health Organization. Global strategy for dengue prevention and control 2012-2020. World Health Organization. 2012. Available at: http://www.who.int/ iris/handle/10665/75303. Accessed 10 April 2018.

8. Gubler DJ. The economic burden of dengue. Am J Trop Med Hyg. 2012;1:86(5):743. https://doi.org/10.4269/ ajtmh.2012.12-0157

9. Gupta E, Dar L, Kapoor G, Broor S. The changing epidemiology of dengue in Delhi, India. Virology Journal. 20061;3(1):92.https://doi.org/10.1186/1743422X-3-92

10. Vairo F, Mboera LE, De Nardo P, et al. Clinical, virologic, and epidemiologic characteristics of dengue outbreak, Dar es Salaam, Tanzania, 2014. Emerg Infect Dis. 2016;22(5):895. https://doi.org/10.3201/eid2205.151462

11. Kauser MM, Kalavathi GP, Radadiya M, et al. Study of Clinical and Laboratory Profile of Dengue Fever in Tertiary Care Hospital in Central Karnataka, India, Global Journal of Medical Research: B Pharma, Drug Discovery, Toxicology and Medicine. 2014;14(5).

12. Ghouth AS, Amarasinghe A, Letson GW. Dengue outbreak in Hadramout, Yemen, 2010: an epidemiological perspective. Am J Trop Med Hyg. 2012;86(6):1072-6.https://doi.org/10.4269/ ajtmh.2012.11-0723

13. Padhi S, Dash M, Panda P, et al. A three year retrospective study on the increasing trend in seroprevalence of dengue infection from southern Odisha, India. Indian J Med Res. 2014;140(5):660.

14. Patel LR. Sero prevalence of Dengue NS-1 Antigen in Tertiary care hospital, Ahmedabad. Ind J Basic and Applied Med Res. 2013;2(7):694-701.

15. Bhatia R, Dash AP, Sunyoto T. Changing epidemiology of dengue in South-East Asia. WHO South-East Asia Journal of Public Health. 2013;2(1):23. https://doi. org/10.4103/2224-3151.115830

16. Kumarasamy V, Chua SK, Hassan Z, Wahab AH, Mohamad M, Chua KB. Evaluating the sensitivity of a commerical dengue NS1 antigen-capture ELISA for early diagnosis of acute dengue virus infection. Singapore Med J. 2007;48(7):669. https://doi. org/10.1016/j.jviromet.2006.11.001

17. Herencia JSS. Laboratory Tests Used in the Diagnostic and Research of Dengue Virus: Present and future; chapter 4 , November $5^{\text {th }}$ 2018. http:// dx.doi.org/10.5772/intechopen.80519. https://doi. org/10.5772/intechopen. 80519

18. Anand KSS, Bettegowda S. Clinical and laboratory pattern of dengue fever: a retrospective study from rural hospital. Galore International Journal of Health Sciences \& Research. 2019;4(3):44-46.

19. Nimmagadda SS, Mahabala C, Boloor A, Raghuram PM, Nayak UA. Atypical Manifestations of Dengue Fever-Where Do We Stand to Day?. J ClinDiagn Res. 2014;8(1):71-3. https://doi.org/10.7860/ JCDR/2014/6885.3960

20. Solanke SN, Pohekar AS, Pohekar JA. Clinical and laboratory profile of dengue fever: a retrospective study. Int J Adv Med. 2019;6:1254-8. https://doi. org/10.18203/2349-3933.ijam20193280 